\title{
Framing Multicultural Capital to Understand Multicultural Education in Practice
}

\author{
Cristina Poyatos Matas, Griffith University, Queensland, Australia \\ Susan Bridges, The University of Hong Kong, China
}

\begin{abstract}
Educational institutions are agents that can support culturally and linguistically diverse communities and promote transformative change in preparing global citizens. The degree of preparedness of citizens to deal with the new multicultural reality that constitutes modern life has real economic implications for a nation's success. By adopting a multicultural capital framework that synthesises current capital theories across fields, we seek to understand how educational institutions can prepare students for a world in which the ability to move across cultures and languages significantly determines an individual's ability to succeed. Middle schooling has been increasingly identified in educational literature as an identifiable stage in schooling that spans traditional notions of primary and secondary schooling and that holds distinct characteristics and needs. Drawing upon ethnographic data from a qualitative, exploratory study, this paper maps educational practices (both pedagogic and institutional) across six middle schools in urban Australia. By mapping these practices to the proposed multicultural capital framework, we identify how culturally proactive educational institutions productively draw upon multicultural capital to foster and promote a distinctly Australian perspective of what constitutes multicultural education.
\end{abstract}

Keywords: Multicultural Education, Multicultural Capital, Middle Schooling

\section{Introduction}

T THILE CURRENT TRENDS in Europe, America and Asia are emphasising the importance of developing pluricultural and plurilingual societies to manage globalization effectively, Australia in some ways remains an Anglocentric oasis in the Asia-Pacific, as Wesley (2009) explains:

\begin{abstract}
"Australia is lagging further and further behind comparable nations in the international skills of its people. At the core of our continued prosperity and security as a global nation must be a capacity to understand and operate in languages, cultures and mindsets other than our own. Over three-quarters of Australians speak English only - making Australia the third most monolingual developed nation in the world." (p. 4)
\end{abstract}

The word multiculturalism itself took on a somewhat pejorative aspect during a long period of conservative government in the period 1996-2007 (Hart, 2006). The then Prime Minister, John Howard, in his final year in power was forced to defend his government's move to change the title of the Department of Immigration and Multiculturalism to the Department of Immigration and Citizenship, saying it was not an attack on multiculturalism itself (Johnston, 2007). As Narushima (2008) reported, the decision of the Howard's government to drop the word "multicultural" from the department's title in 2007 was viewed as a decision

The International Journal of Learning

Volume 16, Number 10, 2009, http://www.Learning-Journal.com, ISSN 1447-9494

(C) Common Ground, Cristina Poyatos Matas, Susan Bridges, All Rights Reserved, Permissions: cg-support@commongroundpublishing.com 
intending to minimise the value of international identities. Even though the current Primer Minister has been reticent in discussing multiculturalism, its government brought the word back into the political arena at the end of 2008 by announcing "the formation of the Australian Multicultural Advisory Council to advise the Rudd's government on promoting social cohesion and stemming racism. Its predecessor was allowed to lapse in 2006 and Australia has been without a multicultural policy since" (Narushima, 2008).

Changing national policies on multilcuturalism are reflected in current international debates on educational models that can support the development of global and intercultural citizens as a desirable outcome of education (Banks, 2009; Bennet, Bennet \& Allen, 2003; Byram, 2008; Nukaga, 2003; Wang, 2004). Multicultural education has been interpreted and implemented by different nations in different ways. As Banks (2009) states in "Western Europe, the movement is often referred to as intercultural education a term used to recognize the desirability for people from different cultures to interact in dynamic and complex ways" ( $p$. 14).

That an international identity can be promoted through the use of an international curriculum in schools is not a new idea. For example, the International Baccalaureate Organization (IBO) founded in 1968 promotes the acquisition of at least one second language in its primary and secondary programmes. In the ensuing decades, the international and global have moved into mainstream education. Speaking from a Singaporean perspective, Lim \& Tay (2009) explained:

"In a globalized world, we need to educate our children on global citizenship. Education should prepare children to be agents of change, rather than just passive observers of world events" (p.1).

In a similar way, a policy goal in the national UK framework for sustainable schools is that by 2020 all schools should be "models of good global citizenship, enriching their educational mission with active support for the well-being of the global environment and community" (Teachernet, 2009). From this perspective, curriculum is seen as a tool "to cultivate the knowledge, values and skills needed to act as globally-aware citizens, and reinforce this through positive activities such as school partnerships and exchanges" (ibid, 2009). Schools in the UK are being encouraged to establish policies that reflect their commitment to global citizenship, and to use their resources to promote these values .

Despite having a Mandarin-speaking ex-diplomat as its prime minister, Australia in the latter half of this decade has been wavering on the issue of language teaching. Unlike countries such as China, Japan, and, from 2010, England, studying a second language in Australian schools remains, in the main, an option with the flow-on effect of diminished uptake in higher education (Dias, LoBianco and Wesley, 2009). In the Australian context, the issue of multiculturalism has occupied a prominence in public debate in Australia that multilingualism has not (Anderson \& LoBianco, 2009; Clyne, 2009; Group of Eight, 2007; Hatoss, 2005; Martín, 2005; Pauwels, 2007).

While multilingualism may have faltered, critical and progressive approaches to school education have promoted pedagogies that support transformative social change. Influenced by American ideas on authentic instruction from the late 90s (Newmann \& Wehlage, 1993; Newmann, 1996) the concept of Productive Pedagogies (PP) was developed in Australia. This was the outcome of the Queensland School Reform Longitudinal Study (Ladwig, Luke, 
\& Lingard, 2000; Lingard, Ladwig, Mills, Bahr, Chant, Warry, Ailwood, Capeness, Christie, Gore, Hayes \& Luke, 2001a, 2001b). This educational framework advocates the centrality of the teacher's role in student engagement in learning and in achieving learning outcomes. Teachers are seen as agents that can make a real difference through their classroom practices. In the state of Queensland, Australia, a longitudinal study tracked 302 classrooms using PP. Four important domains of learning with PP were identified: intellectual quality, connectedness, socially supportive classroom, and recognition of difference. It has been argued that the use of productive pedagogies and productive assessment can lead to improving learning for all students, and in particular for those from disadvantaged backgrounds including students from ethnic cultures (Hayes, Mills, Christie, \& Lingard, 2006). This is why the fourth dimension of the PP educational framework encourages the recognition of difference (cultural knowledge, inclusivity, narrative, group identity, and active citizenship). It's a view that O'Toole (2006) shared, arguing that the school and classroom

"should be a supportive environment where group identity and identities are valued both where difference is viewed positively and where there is a strong sense of community" (p. 3).

While the issue of transformative approaches is evident in the work undertaken through the Productive Pedagogies movement, the disconnection between multilingualism and multiculturalism in Australian policy and education is an issue for further exploration. In this paper we seek to examine how resources, such as language ability, can be drawn upon to contribute to educational models that support global citizenship.

\section{Multicultural Capital}

The multicultural capital framework provides a paradigm that views cultural and linguistic diversity, as O'Toole (2006) suggested, as an asset rather than as a problem. The notion of multicultural capital in the middle schooling arose from data analysis that showed evidence of how five categories of capital contributed to increasing multicultural awareness and knowledge in five Australian schools (Poyatos Matas \& Bridges, 2008). The notion was built on work on culturally problematic and interculturally proactive schools developed by Hicking-Hudson (2003), and expanded prior analysis (Bridges \& Poyatos Matas 2006) exploring concepts such as multicultural education (Banks, 2004) and productive diversity (Kalantzis \& Cope, 1999).

The notion of multicultural capital draws upon five categories of capital established in economic theory and sociology. These are: physical capital (Hicks, 1974), human capital (Becker, 1994); natural capital (Jansson, Hammer, Folke and Costanza, 1994), social capital (Bourdieu, 1986; Coleman, 1988), and cultural capital (Throsby, 1999). When talking about multicultural assets, these five components of multicultural capital were interpreted in the school context as follows:

1. The physical capital is the multicultural material resources available in the schools, such as books, computers, learning program and any other resources.

2. The human capital is determined by its human composition, including the ethnic, language and cultural skills and experiential background of the principal, teachers, students, and administrators, as well as their professional development opportunities. 
3. The natural capital is made of the students and parents, and local communities.

4. The social capital is the use of the school reputation and community networks to take action to facilitate and enrich multicultural education.

5. The cultural capital is the use of cultural phenomena like paintings and posters in buildings, gardens, music, art, food and any other form of cultural production, as well as school mission statements and policies that support diversity and social inclusion in the school. (Poyatos Matas \& Bridges, 2008).

The framework described in this paper provides a coherent means to assess levels of multicultural capital in schools and to assist schools in understanding how their multicultural capital may affect their approaches to education.

\section{Approaches to Multicultural Education}

National approaches to multicultural education arise from very different historical contexts. For example, in the USA, multicultural theories and approaches arose from a history of racial conflict and identity politics (Kanpol \& McLaren, 1995, Green, 1998, Lauter, 2000, Bennet 2003, Ali \& Ancis, 2005, Sinacore \& Enns, 2005). In contrast in Canada, a strong bilingual focus drove multicultural education theory, while in European Union (EU) countries, the focus was on multilingual development enhancing international co-operation and the construction of the European citizen that is pluricultural and plurilinguistic (Council of Europe, 2006; Santos, Alves \& Mendes, 2006; Zirkel \& Cantor, 2004).

Kalantzis and Cope (1999) delineated four principles for a 'postprogressivist pedagogy', including: positive identification of the "cultural stakes in education" with cultural diversity as a resource for access; explicit pedagogy without prejudice to diversity; and education of all students for cultural and linguistic diversity so that they can effectively deal with difference (pp. 262-264).

In developing frameworks for multicultural education in the US, Banks' (2004), put forward a notion of schools as a 'social system' within an interconnected network of social systems arguing that multicultural education should

"help students acquire the knowledge, skills, and attitudes needed to function effectively within the national macroculture, their own microcultures, and within and across other microcultures." (p. 11).

Banks (2004) plotted the way which different schools in the USA integrated along five dimensions of multicultural education: content integration, knowledge construction, an equity pedagogy, prejudice reduction, and empowering school culture and social structure. Content integration refers to the way cultural content from a variety of cultures is integrated into a curriculum.

When using a contribution approach, the simplest level to content integration, the curriculum remains almost unchanged. The content of other cultures and ethnic groups is simply added through special events or celebrations. Thus, external cultures individuals are viewed from a dominant perspective and out of context; cultural or racial inequalities or oppression remain unaddressed. The contribution approach can reinforce stereotyping and promote a superficial view of ethnic cultures. 
The additive approach presents the same problems as the contribution approach, as it allows for the teacher to include content in the curriculum without restructuring it. Therefore, the course retains an essentially the dominant culture point of view.

Banks (2004) also described what he calls the transformative approach. This approach enables students to view concepts from different cultural perspectives. While the previous two approaches promote relatively superficial multicultural learning, where "the other" is objectivised, the transformative approach promotes deep multicultural learning in students, that can lead to transformative learning (Mezirow, 2000) through critical reflection on multicultural content. The use of a transformative approach involves a complete transformation of the curriculum. As Cumming-McCann (2004, p. 11) put it, "to embrace the transformative approach, teachers must be willing to deconstruct their own existing knowledge, explore alternative perspectives critically, research and include voices and ideas other than those traditionally presented to us, and address their own roles in perpetuating racism and oppression.".

The last step of this transformative pedagogical ladder is the decision making and social action approach. This is most challenging level of content integration as it includes all the elements of the transformative approach but additionally requires students to make decisions and take action related to the concept or issue studied.

In Australia, the term 'multicultural education' has taken on a uniquely Australian characteristic in the last three decades in response to different federal and state policy developments (Poyatos Matas \& Bridges 2005). Working with ethnographic data, Poyatos Matas and Bridges (2006) identified that Bank's five domains of multicultural education were present in the multicultural approaches described by the Australian schools that they investigated. In addition, they identified a sixth domain that they described as "productive diversity in action". This last dimension of multicultural education in Australia was found to have five key elements, flexibility, multiplicity, devolution, negotiation, and pluralism (Cope \& Kalantzis, 1997). Educators' accounts reflected that students, teachers, ancillary staff and the wider school community held linguistic and cultural resources that were seen as some form of capital. This capital was then productively exploited to enrich learning experiences within the classroom.

Overall, the literature in multicultural education acknowledges that schools, like the communities they support, are diverse (Banks, 1997; Banks \& McGee Banks, 2004; Massa, 2003). It also, naturally enough, argues that some approaches to multicultural education can produce better results than others (Jennings \& Potter Smith, 2002; Sleeter, 1996). This is because some approaches can influence students (both those in the hegemonic centre and those on the marginalised rims) in transformative ways. Some researchers believe that the promotion of transformational awareness is the main factor contributing to the commitment to multicultural education. However, little is known about what aspects of integrated environments are important for creating transformative change (Paccione, 2000; Pettigrew, 1998; Pettigrew \& Tropp, 2000 in Zirkel \& Cantor, 2004). Interculturalists in Australia express similar concerns citing approaches that objectify the target culture rather than creating intersubjective identities (LoBianco, Liddicoat \& Crozet, 1999). However as Cumming-McCann (2003) argued:

"If the primary goal of multicultural education is transformation, it will happen only when students are given the opportunity to participate in an equitable education, when 
they are informed about existing inequities, and when they are empowered to make decisions to change our society." (p. 11).

Even though the multicultural education literature acknowledges the importance of using transformative approaches, and that different schools vary in their ethnic profiles, this paper argues that this variance may be either a source of strength, or a stumbling block, in shaping the multicultural approach of schools. Diversity in a school population may represent a form of capital that, if it is not recognised, may remain untapped. In what follows, we propose that a concpetualisation of multicultural capital can support multicultural education.

\section{Exploring the Relationship between Multicultural Capital and Approaches to Multicultural Education}

In a previous paper (Poyatos Matas \& Bridges, 2008), the authors developed the notion of multicultural capital in middle schooling, exploring how physical, human, natural, social and cultural capitals are elements of a tertiary concept, multicultural capital. This paper takes the exploration further, examining how the multicultural capital of each school may have influenced their multicultural education choices (see Figure 1).

The multicultural capital of a school is made of different elements that can facilitate optimal multicultural learning environments that are transformative for their teachers and for their students to develop into global citizens (Figure 1).

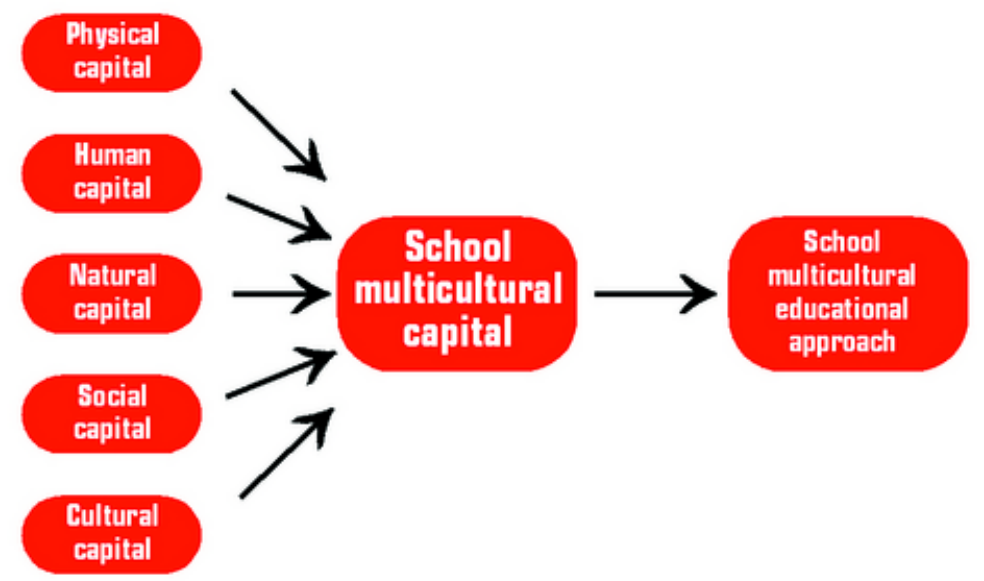

Figure 1: A Model of Multicultural Capital for Multicultural Education

The multidimensional analytical framework developed from this study incorporates elements from the multicultural capital framework (Poyatos Matas \& Bridges, 2008) working in combination with the typology proposed by Hickling-Hudson (2003) that classified schools as interculturally proactive or culturally problematic, and the multidimensional model of multicultural education identified by Banks (2004). The relationship can be illustrated simply, as in Figure 2. That is, when a school draws upon its multicultural capital as teaching and learning resources, it adopts a transformative approach to multicultural education that develops 
intersubjectivity and social awareness. Schools drawing up on these resources and applying these approaches can then be described as 'interculturally proactive'.

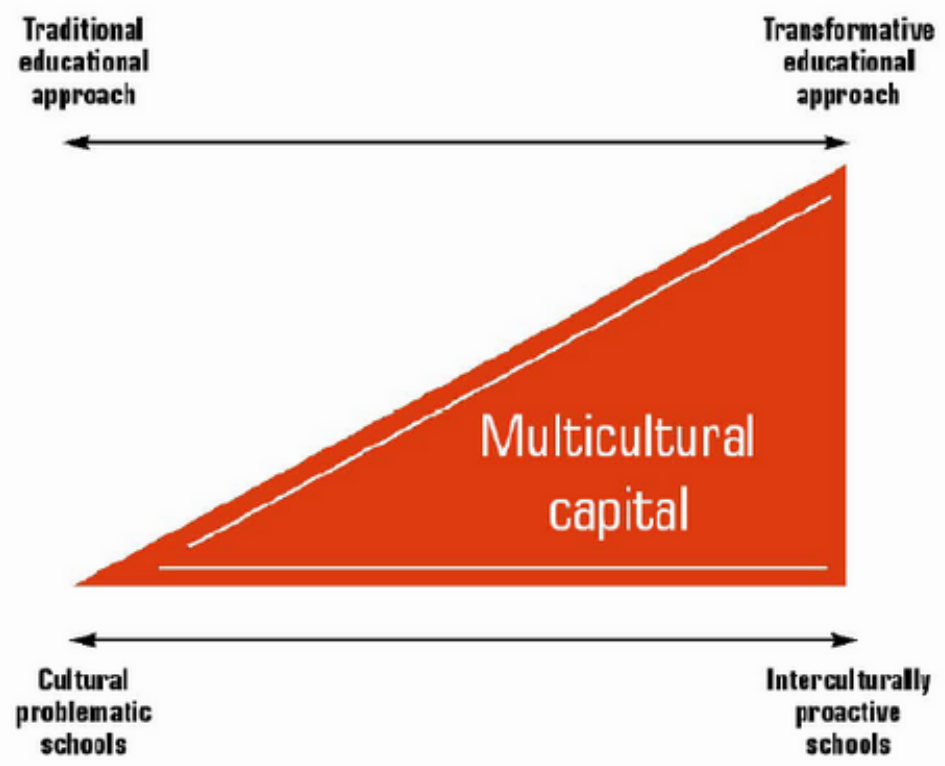

Figure 2: The Relationship between Multicultural Capital, Typology and Approaches to Multicultural Education

\section{The Study}

Middle schooling is considered an important stage of education because it is the transition between the primary school and the secondary school. This transition has a real impact in student achievement (Carrington, 2006). At the level of middle schooling, conceptualizations of the term of multiculturalism and its enactment have been found to be varied (Bridges \& Poyatos Matas, 2006). However, we need to learn more about what contributes to successful multicultural education approaches, and the role that multicultural capital may play to support multicultural education in middle schooling.

The small scale study reported here explores the relationship between the multicultural capital of six middle school and the approaches to multicultural education used by its principals and teachers (see also Poyatos Matas \& Bridges, 2008). The data was collected during school visits between 2004 and 2005 and included transcribed teacher interviews as well as school documents. The latter included brochures, web pages, newsletters, policies, and curriculum plans. Additionally, focus group interviews were conducted with key stakeholders (principals, curriculum leaders and teachers) in the selected primary schools.

A total of 25 primary school educators participated in the interviews, including six school principals, 18 teachers, and one teacher aide. Principals and teachers participating in the study provided information on their local school contexts; their own philosophy on 'multiculturalism' or 'cultural and linguistic diversity' as they relate to education; their strategies 
and resources for promoting intercultural understanding; and their professional development needs for the teaching and learning of multicultural awareness and intercultural communication.

The data were coded and content analysed (see Poyatos Matas \& Bridges, 2008), with five of the schools emerging as having a strong pro-active approach to multicultural education. These schools, interestingly, also self-identified as being models of multicultural education, even though they varied significantly in terms of enactment.

In the following analysis, situational subjectivity, referring to the perspective the researcher brings to the analysis (Glesne \& Peshkin, 1992) is acknowledged. However, research colleagues, including experts in economics and education, were involved in reviewing our research processes and findings to make the findings reliable and to control situational subjectivity (Creswell \& Miller, 2000).

All written records and transcripts of interviews were initially reviewed to develop a broad picture of the data, before a more detailed analysis of the data, looking for patterns, categories and themes was conducted. Relevant illustrative examples and quotations were extracted to illustrate the data (Descombe, 2005; Freeman, 2003; Miles \& Huberman, 1994).

Even though initially five of the schools participating in the study were classified as interculturally proactive, a closer examination of the data using this multidimensional framework revealed new insights.

\section{Finding 1: Principals and Teachers Demonstrated Awareness and Appreciation of the Multicultural Assets within their Schools}

Even though the term multicultural capital was not used during the data collection, but arose as a result of the study, teachers and principals in many cases exhibited implicit awareness that multicultural variables were a source of strength for the school infrastructure.

For example, the following principal acknowledged the natural multicultural resources of his school were low.

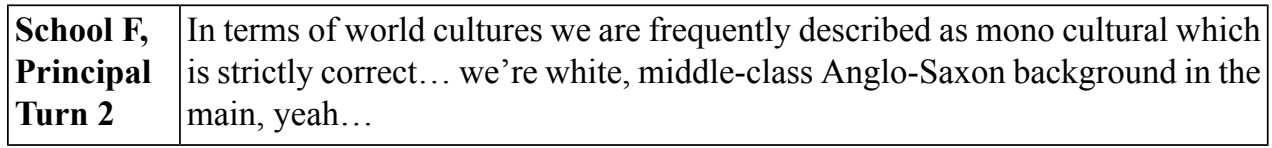

A teacher took up the same theme in his comments, showing awareness of variability in schools in their multicultural 'assets", and how these influence their teaching approaches.

\begin{tabular}{|l|l|}
\hline $\begin{array}{l}\text { School E, } \\
\text { Teachers } \\
\text { Turns 172-176 }\end{array}$ & F: We also make the assumption that every school is like this but its not! \\
& $\begin{array}{l}\text { M: and actually that the rest of Australian is like this school too I think we } \\
\text { all stand by that assumption that everyone is open minded and accepting } \\
\text { and values difference and diversity and I don't think that's necessarily the } \\
\text { reality. }\end{array}$ \\
\hline
\end{tabular}


The teachers also mentioned that the high multicultural capital levels of their schools contributed to the transformation of their teaching methods, and as a result they engaged in their own form of multicultural learning:

School D, I remember the first time I marked the roll here; it was like (laughs)... trying Teacher to pronounce the names. Yeah, still that - I am still learning... Turn 135

In the following example, we can also see how one of the teachers is driven into growing as a teacher and how she made use of the multicultural capital in her school to provide a rich learning environment for her students.

\begin{tabular}{|l|l|}
\hline $\begin{array}{l}\text { School D, } \\
\text { Teacher } \\
\text { Turn 2 }\end{array}$ & $\begin{array}{l}\text { Last year was a classic for me, it was really interesting, I had on day one a little } \\
\text { boy from China and he had no English at all and there I was on day one and } \\
\text { the rush of it all and this little boy that did not understand anything that was } \\
\text { going on. I'm there saying okay unpack, you know you're books and put them } \\
\text { in and he's... and that-I didn't know until someone come up and said hey, he } \\
\text { doesn't understand... so that was a huge challenge for me because at first I } \\
\text { thought oh God, so then I went and saw the ESL...and she got some literature } \\
\text { for me to read and there was a lot of literature but then again my time was } \\
\text { really... I read a little bit of it and then made up the rest myself so.. he caught } \\
\text { on really, really quickly and by the end of the year he was writing really well... } \\
\text { his reading level was I think... it definitely was acceptable to go on to the next } \\
\text { year level, it just grew really quickly once he learnt the letters and sounds and } \\
\text { things like that and the other kids they became mentors to him as well and } \\
\text { teachers... so he'd usually get buddied up with the other kids and they would } \\
\text { label things, so we'd labelled the room and read lots... }\end{array}$ \\
\hline
\end{tabular}

The principals and teachers were not the only ones aware of their school's multicultural capital. Some parents were actively enrolling their children in schools because of perceived high levels of multicultural capital, in the forms of demographic composition, resources and approaches to multicultural education.

\begin{tabular}{|l|l|}
\hline $\begin{array}{l}\text { School E, } \\
\text { Teacher } \\
\text { Turn 19 } 19\end{array}$ & $\begin{array}{l}\text { We've got a lot of people choosing this school on that basis; they want their } \\
\text { children exposed to this type of education, which is a multi-culturally as apposed } \\
\text { to mono-cultural sort of education. So, if you look at even our school in our } \\
\text { inner city area, schools like X and Y are fairly mono-cultural like its quite un- } \\
\text { usual to have a child that comes from a non-white Anglo-Saxon background } \\
\text { in those schools, so they want them to have a type of that experienced as op- } \\
\text { posed to the mono-cultural type experience. }\end{array}$ \\
\hline
\end{tabular}

Some schools have gained evidence of how important their multicultural diversity was to parents through their school reviews, as the following example shows. 


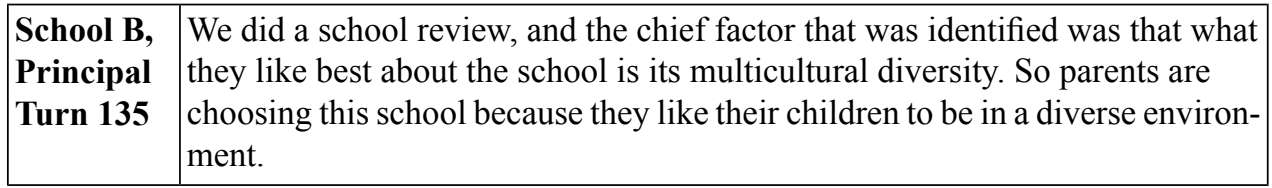

\section{Finding 2: Acessing Multicultural Capital in Middle Schools can Promote Intercultural Proactivity and Support the use of Transformative Multicultural Approaches to Education}

The principals and teachers participating in the study were asked to describe the particular approaches that they used in the school for promoting multicultural and intercultural understanding, as well as to comment on the multicultural resources that they had to support this.

The degree of available multicultural capital determined, to varying degrees, the multicultural education approach adopted. It was found that when the multicultural capital of the school was limited, the school became culturally problematic (see Figure 2 ) and as a result may adopt what Banks (2004) would critique as a 'a contributions approach' to multicultural content integration, which could lead to stereotyping other cultures.

One of the school principals demonstrated real awareness of the limited multicultural capital of his school. He expressed concerns about the impact that the absence of multicultural resources might have on the school's ability to prepare students for a global world, as their approach to multicultural education was basically driven by the Languages Other Than English (LOTE) teacher and by the Studies of Society and Environment (SOSE) classes.

\begin{tabular}{|l|l|}
\hline $\begin{array}{l}\text { School F, } \\
\text { Principal } \\
\text { Turn 7 }\end{array}$ & $\begin{array}{l}\text { Again the curriculum opportunities that pop up because of outcome requirements } \\
\text { and SOSE or project opportunities that arise... we'll dive in and use those. The } \\
\text { strongest approach is really through the LOTE program because that's a con- } \\
\text { sistent thread all throughout the school. }\end{array}$ \\
\hline
\end{tabular}

Even when teachers have a commitment to progressive, transformative pedagogy, the lack of access to multicultural capital in a school may lead to the more objectivist, 'tourist' approaches. As one teacher explained:

\begin{tabular}{|l|l|}
\hline $\begin{array}{l}\text { School F, } \\
\text { Teacher } \\
\text { Turn 13 }\end{array}$ & $\begin{array}{l}\text { Over the years, I did a multi-cultural day where I had parents who had diverse } \\
\text { cultural backgrounds. We had a mother who was Spanish. She came and did } \\
\text { some cooking with us and we had another boy who had German back- } \\
\text { ground-his mother came and made some German puppets and we had one } \\
\text { mother who was not from a Japanese background but she'd lived in Japan. She } \\
\text { came and did some cooking with the children, so at those times I try to find } \\
\text { people within the community or experts to come in and do something special } \\
\text { with the children, but mostly my resources that I just devise myself. }\end{array}$ \\
\hline
\end{tabular}

In contrast, the analysis of the interview data showed that a school with high levels of multicultural capital was more able to engage with transformative content integration and knowledge construction to empower students' critical engagement with biases within a dis- 
cipline. It also showed that in the schools with high levels of multicultural capital the teachers engaged more with equity pedagogy and creating a school culture that empowers all students, despite their racial or ethnic background.

School D, We have a philosophy of inclusion on the multicultural aspect of the school... Principal We do promote the linguistic diversities and we try to make sure that everybody Turn 182 is feeling good about themselves and their language,

In particular it was found that those schools with high levels of human multicultural capital, that is with principals, teachers and other members of the staff with a rich multicultural and multilingual background and a multicultural educational experience, demonstrated the highest levels of commitment to the promotion of transformational multicultural awareness in their school. As noted by the School D teacher's interaction with the young Chinese boy, challenges brought about by the multicultural capital of a school can in fact bring about transformational change in teachers as well as students.

It was found that principals play a very important role in promoting whole school and integrative approaches to multicultural education, drawing on a school's multicultural capital. The data analysis indicated that these principals had a transformational leadership approach, an approach that gave rise to strong teacher support for the principals. These principals enabled the teachers to "feel the leadership" (Gunter, 2001) and to be protagonist in the positive changes taking place in their schools.

School C, I try to encourage with teachers that we don't necessarily know everything and Principal sometimes there are parents that are far better at sharing information or stories Turn 24 about their lives and backgrounds with the kids, and by tapping into them we can help to facilitate that which makes, I think, us better teachers because we are able to provide those richer experiences for the kids, so the teachers do that as well.

The teachers from schools with high levels of multicultural capital pointed out that elements such as school demographics (natural capital) and having a multicultural vision of Australia in the mission statement of the school (cultural capital) influenced their pedagogical choices and encouraged them to explore new integrative ways. In this way, different school contexts provided different possibilities for them to reflect on their approaches to multicultural education, as this teacher explained:

\begin{tabular}{|l|l|}
\hline $\begin{array}{l}\text { School E } \\
\text { Teacher } \\
\text { Turn 192 }\end{array}$ & $\begin{array}{l}\text { What was new for me, when I came to this school, was the values and belief } \\
\text { statement of the school which was built on the multicultural notion of the } \\
\text { school, and whenever you think about it, when before I came here how would } \\
\text { I incorporate multicultural understanding, you do all that really surface stuff, } \\
\text { the dancing and the cooking thing. }\end{array}$ \\
\hline
\end{tabular}

It was a theme repeated by a number of other teachers. "I think having been at this school for so long, it really got me into that language," one teacher said. A school with high multicultural capital gave "children the opportunity to bring their own knowledge to school...and [that's] been one of our most wonderful opportunities," another added. 


\section{Finding 3: Schools with High Levels of Multicultural Capital are more Likely to use a Whole-School Transformative Approach to Multicultural Education}

In this study the five schools with high levels of multicultural capital were found to productively access this resource to develop a more holistic approach grounded in the school's ethos. These schools were interculturally proactive and used a whole-school approach to multicultural education aiming to provide equality in learning, building on the strengths of their diversity, rather than a subject or curriculum specific approach.

\begin{tabular}{|c|c|}
\hline $\begin{array}{l}\text { School C, } \\
\text { Principal } \\
20\end{array}$ & $\begin{array}{l}\text { We try to embed through our curriculum program things like tolerance and } \\
\text { acceptance and understanding of various cultures and backgrounds, and so } \\
\text { forth. Because of that, it also means that through our music program, the sorts } \\
\text { of music that they'll be singing range from, you know... they'll do things in } \\
\text { different languages... }\end{array}$ \\
\hline
\end{tabular}

These schools with a whole-school approach to multicultural education adopted more transformative approaches to multicultural education and were aware of more traditional approaches that objectify the target culture rather than creating intersubjective identities, as the following teacher from one of these schools demonstrated.

\begin{tabular}{|c|c|}
\hline $\begin{array}{l}\text { School E, } \\
\text { Teacher } \\
39\end{array}$ & $\begin{array}{l}\text { We try to use multiculturalism to underpin the way that we plan our units and } \\
\text { learning experiences so, um, you now [are] using the children's cultural heritage } \\
\text { is something that is second nature and we try to harness it at every opportunity } \\
\text { as well so we have a set of values and beliefs that set out what we believe, what } \\
\text { multiculturalism is about and how we want to harness that.... We are a school } \\
\text { that has a multicultural curriculum as apposed to a celebrating multiculturalism } \\
\text { though one off cultural days and festivals and things like that. }\end{array}$ \\
\hline
\end{tabular}

\section{Conclusion}

The concept of multicultural capital has been employed here to assess how available resources and the accessing of these resources can affect educational approaches. As such, the multicultural capital framework provides a paradigm that views diversity as an asset rather than as a problem (Poyatos Matas \& Bridges, 2008). It adds another variable to the equation that could help us to understand multicultural education and to take a more positive approach to diversity as in the productive diversity movement (Kalantzis \& Cope, 1999).

In the qualitative exploratory study reported here, a multidimensional analytical framework incorporating elements from the multicultural capital framework was used in combination with Hickling-Hudson's (2003) typology and Banks' (2004) multidimensional model of multicultural education to analyse data collected from six middle schools.

The findings indicate that the implementation of multicultural education varies amongst different schools and the approaches implemented by each school are influenced by their multicultural capital. Furthermore, the principals and teachers, part of the human multicultural capital, are pivotal in determining the degree to which multiculturalism is embraced at whole school level. The study also shows that lower levels of multicultural capital may make 
a school culturally problematic and may lead to promotion of the use of educational approaches that objectify "the other", with cultures then viewed from the dominant perspective.

In contrast, it was found that those schools able to draw on their existent high levels of multicultural capital are interculturally proactive with teachers employing multicultural educational approaches that are more transformative in nature. For some schools, engaging teachers in deconstructing their own multicultural belief system and enabling students to see concepts from several cultural and ethnic perspectives supported transformative learning for both staff and students. Therefore, multicultural capital in middle schools to some degree determines the use of transformative multicultural approaches to education.

However, this study raises as many questions as answers. While we argue that there is a relationship between multicultural capital and transformative approaches, the causal sequence of enactment and success are not clear. How do we support schools with low levels of multicultural capital in helping their students to develop as global citizens able to communicate interculturally? How can multilingualism be more centrally aligned with a pedagogy that embraces multicultural education? How can we train teachers to embrace transformative approaches, or will a transformative approach simply arise by adding other elements of multicultural capital to the mix? If we provide teachers with transformative multicultural experiences, what impact would that have in their approaches to multicultural education?

The findings reported in this article are relevant to advancing our understanding of how the available multicultural capital of schools may affect the multicultural approaches that they adopt. However, the authors acknowledge that these results are based on a small scale study. Further research using a wider data base could investigate the possible utility of this new conceptualisation of multicultural capital in order to examine its possible utility for supporting positive changes for transformative approaches to multicultural education. This may hold implications not only for curriculum design, but also for school management and teacher education (both pre-service and in-service). Also a wider database would allow the inclusion of non-metropolitan schools and could examine the utility of these reconceptualisations in regional and rural educational settings.

\section{Acknowledgements}

We would like to thank all the participants who shared their experiences in this study, Dr Olav Muurlink for his editorial comments and graphic assistance, and Mr Michael Bridges for his transcription assistance.

\section{References}

Ali, S. \& Ancis, J. (2005). Multicultural education and critical pedagogy approaches. In C.Z Enns \& A.L Sinacore (Eds.), Teaching and social justice: Integrating multicultural and feminist theories in the classroom (pp. 69-84).Washington: American Psychological Association.

Anderson, K. \& Lo Bianco, J. (2009, September 2). Speak, and ye shall find knowledge. The Australian, p. 39.

Banks, J. A. (1998). Approaches to multicultural curricular reform. In Lee, E., Menkart, D., \& Okazawa-Rey, M. (eds.). Beyond Heroes and Holidays: A Practical Guide to K-12 Antiracist, Multicultural Education and Staff Development. , Washington, DC: Network of Educators on the Americas.

Banks, J. A. (1997). Educating Citizens in a Multicultural Society. Teachers College Press, New York. 
Banks, J. (2004). Multicultural education: Characteristics and goals. In J. A. Banks \& C. A. McGee Banks (Eds.), Multicultural education: Issues and perspectives (4th ed. pp. 3-30). Hoboken, NJ: John Wiley \& Sons.

Banks, J. (2009) Multicultural education: Dimensions and Paradigms. In James Banks (ed.), The Routledge International Companion to Multicultural Education (pp. 9-32). New York: Routledge

Banks, J. \& McGee Banks, C. (2004) Handbook of Research on Multicultural Education, 2nd ed. San Francisco, CA: Jossey-Bass

Becker, G. (1994) Human Capital. , New York: Columbia University Press.

Bennet, C. (2003). Comprehensive multicultural education: Theory and practice. London: Allyn \& Bacon.

Bennet, J. Bennet, M. \& Allen, W. (2003). Developing Intercultural competence in the language classroom. In D. Lange and R. Michael Paige (eds), Culture as a core: perspectives on culture in second language learning education. Place? Greenwich, CT: Information Age Publishing.

Bianco, J., Liddicoat, A. \& Crozet, C. (1999) Striving for the third place: intercultural competence through language education. Melbourne: Language Australia.

Bourdieu, P. (1986) The Forms of Capital, in John G. Richardson (ed.), Handbook of Theory and Research for the Sociology of Education (pp. 241-258). New York: Greenwood.

Bridges, S \& Poyatos Matas, C. (2006). Investigating multiculturalism as policy and practice in the middle years of schooling: An Australian study. International Journal of Diversity in Organisations, Communities and Nations (6) 2, 88-98.

Byram, M. (2008). From foreign language education to education for intercultural citizenship: Essays and reflections. , Clevedon: Multilingual Matters.

Carrington, V. (2006). Rethinking middle years: early adolescents, schooling and digital culture. Crows Nest, N.S.W. Australia: Allen \& Unwin.

Clyne, M. (2009). What a lode of language. The Australian, 19 August 2009.

Cope, B. \& Kalantzis, M. (1997). Productive diversity: A new Australian model for work and management. Annandale: Pluto Press.

Clumming-McCann, A. (2003) Multicultural education: Connecting theory and practice. Focus on Basics: Connecting research and practice, 6, B, 9-12.

Coleman, J. (1986). Social Capital in the Creation of Human Capital. American Journal of Sociology, 94 (Issue Supplement): S95-S120.

Council of Europe (2006). Plurilingual education in Europe: 50 years of International cooperation. Strasbourg: Language Policy Division.

Creswell, J. \& Miller, D. (2000). Determining validity in qualitative enquiry. Theory into practice, 39 (3), 124-130.

Dias, M. (Story researcher and producer), Lobianco, J. \& Wesley, M. (Interviewees). (2009, June 27). Building a bi-lingual Australia. Retrieved from http:/www.abc.net.au/rn/saturdayextra/stories/2009/2608580.htm

Descombe, M. (2005). The good researcher guide for small-scale social research projects. Maidenhead: Open University Press.

Freebody, P. (2003). Qualitative research in education: Interaction and practice. London: SAGE Publications.

Glesne, C., \& Peshkin, A. (1992). Becoming qualitative researchers: An introduction. White Plains, NY: Longman.

Guba, D. \& Lincoln, Y. (1988). Naturalistic and rationalistic enquiry. In T. Husén \& T. Postlethwaite (Eds.) International Encyclopedia of Education ( $2^{\text {nd }}$ edition) (pp.81-85). Oxford: Pergamon.

Green, J. M. (1998) Educational Multiculturalism, Critical Pluralism, and Deep Democracy. In Cynthia Willett (Ed.), Theorizing Multiculturalism: A Guide to the Current Debate (pp 422-448). Malden, Mass: Blackwell Publishers, Inc. 
Group of Eight Australia's Leading Universities (2007). Languages in crisis: A rescue plan for Australia. Retrieved from http://www.go8.edu.au/storage/go8statements/2007/Go8_Languages_in_Crisis_Discussion_Paper.pdf

Gunter, H. (2001). Critical approaches to leadership in education. Journal of Education Enquiry, 2 (2), 94-108.

Hart, C. (2006, November 4). Multiculturalism is a dirty word. The Australian. Retrieved from http://www.theaustralian.news.com.au/story/0,20867,20697488-601,00.html

Hayes, D. Mills, M. Christie, P. and Lingard, B. (2006). Teachers and schooling making a difference: productive pedagogies, assessment and performance. N.S.W. Australia: Allen \& Unwin.

Hatoss, A. (2005) Sustainable multilingualism as an essential characteristic of multicultural societies: the case of Australia. In: Language, Attitudes and Education in Multilingual Cities, 27-29 May 2004, Brussels, Belgium.

Hicks, J. (1974). Capital Controversies: Ancient and Modern. American Economic Review, 64, 301-316.

Hickling Hudson, A. (2003) Multicultural education and the postcolonial turn. Policy futures in education, 1 (2), 381-401.

Jansson AM., Hammer M., Folke C., \& Costanza R., (Eds.) (1994) Investing in Natural Capital: The Ecological Economics Approach to Sustainability. Island Press, Washington D.C.

Jennings, L. and Potter Smith, C. (2002). Examining the role of critical inquiry for transformative practices: Two joint case studies of multicultural teacher education. Teachers College Record, 104 (3), 456-481.

Johnston, T. (2007, January 24). Weakened, Howard reassigns ministries. International Herald Tribune.

Kalantzis, M. \& Cope, B. (1999). Multicultural education: Transforming the mainstream. In S. May (Ed.), Critical multiculturalism (pp. 245-276). London: Falmer Press.

Kanpol, B. \& McLaren, P. (1995) Critical Multiculturalism: Uncommon Voices in a Common Struggle. Westport, CT: Bergin \& Garvey.

Ladwig, J.G., Luke, A. \& Lingard, R. (2000). Redefining school reform: The social-theoretical rationale of the Queensland school reform longitudinal study. St Lucia: University of Queensland Graduate School of Education.

Lauter, P. (2000). Feminism, multiculturalism, and the colonial tradition. Transformations, 111(2), 69.

Lim, C.Y. \& Tay, L.Y, (2009). Turning Students into Global Citizens in a School Setting Retrieved from http://www.unesco.sg/files/global-citizens-school-setting.pdf

Lingard, B, Ladwig, J, Mills, M, Bahr, M, Chant, D, Warry, M, Ailwood, J, Capeness, R,

Christie, P, Gore, J, Hayes, D \& Luke, A 2001a, Queensland School Reform Longitudinal Study: Final report, vol.1, Report prepared for Education Queensland by the School of Education, The University of Queensland, Brisbane.

---- 2001b, Queensland School Reform Longitudinal Study: Supplementary Materials, Report prepared for Education Queensland by the School of Education, The University of Queensland, Brisbane.

Martín, M.D. (2005). Permanent Crisis, Tenuous Persistence Foreign languages in Australian universities. Arts and Humanities in Higher Education, 4 (1), pp. 53-75.

Massa, J. (2003). Teaching and learning in a multicultural classroom. Australia: James Nicholas Publishers.

Message, k. (2009). Culture, citizenship and Australian multiculturalism: The contest over identity formation at the National Museum of Australi. Humanities Research Vol XV. No. 2. Retrieved from http://epress.anu.edu.au/hrj/2009_02/pdf/04.pdf

Mezirow, J. (2000). Learning as transformation: Critical perspectives on a theory in progress. San Francisco: Jossey-Bass.

Miles, M. \& Huberman, A. (1994). Qualitative data analysis: A source of new methods (2nd ed). London: Sage. 


\section{THE INTERNATIONAL JOURNAL OF LEARNING}

Narushima, Y. (2008, December 17). Mixing pot is back in multicultural Australia. Sydney Morning Herald.

Newmann, F. (ed). (1996). Authentic Assessment: restructuring schools for intellectual quality. San Francisco: Josey-Bass.

Newmann, F. M., \& Wehlage, G. G. (1993). Standards for authentic instruction. Educational Leadership, $50(7), 8-12$.

Nukaga, M. (2003). Japanesse education in an era of internationalization: A case study of an emerging multicultural coexistence model. International Journal of Japanesse Sociology, 12, pp. 7994.

O’Toole, J. (2006).The Arts as Productive Pedagogies. Retrieved from http://portal.unesco.org/culture/en/files/30204/11415100201John_O'Toole.pdf/John\%2BO’Toole.pdf

Pauwels, A. (2007). Mantaining a language other than English through higher education in Australia. In Pauwels, A. Winter, \& J. Lo Bianco, J. (eds), Maintaining Minority languages in Transnational Contexts, London: Palgrave Macmillian.

Poyatos Matas, C. \& Bridges, S. (2005). Federal and state policies on multiculturalism and the teaching of culture: A focus on primary education. Proceedings of the 2005 Australian Teacher Education Association Conference. Brisbane: Griffith University.

Poyatos Matas, C. \& Bridges, S. (2008) Multicultural Capital in Middle Schooling. International Journal of Diversity in Organisations, Communities and Nations (8) 2, pp. 1-17.

Santos Alves, S. \& Mendes, L. (2006). Awareness and Practice of plurilingualism and intercomprehension in Europe. Language and Intercultural Communication, 6 (3/4), pp.211-218.

Sinacore, A. \& Enns C. (2005) Multicultural and feminist literatures: Themes, dimensions and variations. In C.Z Enns \& A.L Sinacore (Eds.), Teaching and social justice: Integrating multicultural and feminist theories in the classroom. Washington: American Psychological Association.

Sleeter, C. (1996). Multicultural Education as Social Activism. SUNY Press, Albany, NY.

Teachernet (2009). The National Framework for Sustainable Schools. Global citizenship. Retrieved from http://www.teachernet.gov.uk/sustainableschools/framework/framework_detail.cfm?id=9

Throsby, D. (1999) Cultural capital. Journal of Cultural Economics, 23, pp. 3-12.

Wang, L. (2004). Multiculturalism in Taiwan. International Journal of Cultural Policy, 10 (3), pp. 301-318.

Wells, R. (2008). The global and multicultural: Opportunities, challenges, and suggestions for teacher education. Multicultural perspectives, 10(3), 142-149.

Wesley, M. (2009). Building an Asia-Literate Australia: An Australian Strategy for Asian Language Proficiency. Retrieved from http://www.griffith.edu.au/_data/assets/pdf_file/0006/143628/building-asia-literate-brochure.pdf 


\section{About the Authors}

Dr. Cristina Poyatos Matas

Cristina is a senior lecturer at Griffith University in the School of Languages and Linguistics. Her interest in teaching innovations is internationally recognised, and she has twice been selected as a finalist in the prestigious Australian Awards for University Teaching, and, in 2003, she was awarded a HERDSA Teaching Fellowship. She was awarded the Higher Education Research and Development Society of Australasia Annual International Conference Prize, and in 2007 she received Research Excellence Award (with Dr Bridges) of the International Journal of Diversity in Organisations, Communities and Nations. She has delivered workshops and keynote addresses to academics in France, Spain, New Zealand, Malaysia, Hong Kong, England, and USA. Her research is in the areas of multicultural education, ethnolinguistics, student centred assessment, research supervision and academic well-being. She is currently PhD studies program co-ordinator for Griffith University's School of Languages and Linguistics.

\section{Dr. Susan Bridges}

Susan Bridges has taught in mainstream and higher education for the past 25 years. She is currently an assistant professor with the Faculty of Dentistry at The University of Hong Kong where she works in curriculum design and e-learning. Previously, she was a research fellow with the Faculty of Education at Griffith University. Her research focuses on pedagogy, cultural and linguistic diversity and interaction. Recent co-authored publications on multicultural education and global academic movement have been recognised with Common Ground International Awards of Excellence in 2007 (winner) and 2008 (runner-up). 